\title{
Predatory crab size diversity and bivalve consumption in oyster reefs
}

\author{
Benjamin J. Toscano ${ }^{1, *}$, Blaine D. Griffen ${ }^{1,2}$ \\ ${ }^{1}$ Department of Biological Sciences, and ${ }^{2}$ Marine Science Program, University of South Carolina, Columbia, \\ South Carolina 29208, USA
}

\begin{abstract}
Body size is widely recognized as an important functional trait of predators due to its influence on prey consumption rates and diet breadth. Yet it remains unclear how the diversity of this trait within predator populations affects prey communities. To test the effects of intraspecific predator size diversity, we manipulated the number of size classes (i.e. size diversity) in the xanthid crab Panopeus herbstii and measured their consumption of the bivalve community in intertidal oyster (Crassostrea virginica) reefs. In the experiment, the presence of large crabs, but not size diversity, significantly affected total prey biomass consumption. The largest size class of crabs effectively consumed all bivalve prey types whereas smaller crabs were restricted in diet breadth. As such, any treatment containing large crabs had significantly greater total prey consumption and more uniform consumption across the prey community than those without. We also investigated the potential for oyster harvest to alter crab population size structure at the study site (North Inlet, South Carolina, USA). Anthropogenic oyster harvest acts to compress the surficial shell layer in reefs and could reduce crab body size by reducing the availability of refuges for large crabs. Therefore, we tested for a relationship between the height of the shell layer and average crab body size in the field. In the field survey, average crab body size decreased with decreasing height of the shell layer. Thus, our data suggests that oyster harvesting practices have the potential to skew crab size structure towards a preponderance of small individuals, thereby compromising the trophic transfer that occurs in unperturbed reefs.
\end{abstract}

KEY WORDS: Biodiversity · Crassostrea virginica $\cdot$ Functional trait $\cdot$ Intraspecific $\cdot$ Niche shift Ontogenetic $\cdot$ Panopeus herbstii.

\section{INTRODUCTION}

Predator body size is a key functional trait with important consequences for how predators affect prey communities (Elton 1927, Kneib \& Stiven 1982, Werner \& Gilliam 1984, Woodward et al. 2005, Brose 2010). Predator populations are naturally heterogeneous in body size, and different sized conspecifics often have divergent ecological effects (Polis 1984, Werner \& Gilliam 1984, Werner 1992). For example, body size affects individual prey consumption rates due to differing energetic requirements or handling times (Mittelbach 1981, Brose 2010), and can also influence diet diversity or trophic position due to changes in size of the feeding apparatus (Hardy 1924, Arim et al. 2010). Incorporating such intraspecific functional variation in both empirical and theoretical frameworks has major consequences for trophic interactions and food web dynamics (Rudolf 2007, Okuyama 2008, Bolnick et al. 2011, Rudolf \& Lafferty 2011).

Body size variation within predators represents a potentially important, yet understudied level of predator biodiversity (i.e. intraspecific diversity). Previous studies of predator biodiversity have focused almost exclusively on predator species richness (i.e. 
interspecific diversity) (Bruno \& Cardinale 2008, Hillebrand \& Matthiessen 2009, Reiss et al. 2009, Finke \& Snyder 2010). These studies indicate that functional diversity (i.e. the range of functional traits among predator species), rather than richness per se, drives ecological processes such as prey suppression (Schmitz 2007, 2009, Bruno \& Cardinale 2008). For example, crab species that consume different prey types fulfill complementary functional roles in the rocky intertidal (Griffin et al. 2008). Such resource partitioning allows greater resource use efficiency, thus enhancing ecological process rates (Finke \& Snyder 2008, Griffin et al. 2008).

Mechanisms such as resource partitioning could apply similarly to the ecological effects of intraspecific body size diversity. For example, the partitioning of food resources is common within predator species (Polis 1984), where small and large size classes of a predator often have non-overlapping diets (Stoner \& Livingston 1984). Such ontogenetic (i.e. growth-related) shifts are widespread throughout fish, amphibians, reptiles and invertebrate taxa (Werner \& Gilliam 1984). While some of these species undergo major morphological and habitat transitions that are associated with diet differences (e.g. amphibians), intraspecific partitioning is also common in predators that exhibit simple allometric growth (Werner \& Gilliam 1984). Other types of intraspecific phenotypic variation (e.g. morphology, sex, individual specialization; Bolnick et al. 2003) can have similar effects on diet variation within species. In some communities, such niche variation within predator species exceeds variation among predator species means (e.g. Woodward \& Hildrew 2002, Arim et al. 2010). Particularly in these communities, intraspecific predator diversity could have ramifications for consumptive effects in food webs.

Furthermore, intraspecific predator size diversity is being altered by anthropogenic stressors. For example, harvesting practices that target the largest individuals in a population (i.e. minimum size limits) skew population size structure towards smaller individuals (Fisher et al. 2010, Shackell et al. 2010), thus reducing body size diversity within predator populations. Harvesting can also indirectly affect predator size structure by decreasing intraspecific competition, which in turn increases growth rates and sizeat-age in some harvested populations (Law 2000).

The mud crab Panopeus herbstii is common along the Atlantic and gulf coasts of the USA, where it inhabits hard-bottom substrates in the intertidal zone, especially oyster reefs (Williams 1984). Throughout its range, this crab is a major consumer of mollusks (particularly bivalves and gastropods), affecting their local distribution and population structure (McDermott 1960, Seed 1980, Bisker \& Castagna 1987, Milke \& Kennedy 2001). Within our study site (North Inlet, South Carolina), this crab is the numerically- and biomass-dominant resident predator in intertidal reefs created by the eastern oyster Crassostrea virginica (Dame 1979). These reefs fringe the banks of tidal creeks throughout North Inlet and provide the only natural hard substrate available, supporting food webs with major trophic levels (e.g. primary producers, primary consumers, predators) (Dame 1979). Here, P. herbstii feeds on a community of bivalves including $C$. virginica, scorched mussels Brachidontes exustus and ribbed mussels Geukensia demissa (Dame \& Patten 1981, Dame \& Vernberg 1982). Feeding preference experiments conducted in the laboratory show that larger $P$. herbstii preferentially consume larger bivalves (Seed 1980, Whetstone \& Eversole 1981). In North Inlet's reefs, bivalve prey size varies considerably (see Fig. 1), providing opportunity for intraspecific prey resource partitioning. These bivalves in turn provide important ecosystem services to North Inlet including benthic-pelagic coupling and erosion control (Dame \& Libes 1993).

While Panopeus herbstii is not harvested directly, the harvest of their biogenic habitat (oysters) is potentially altering the size distribution of $P$. herbstii in North Inlet's reefs. Oyster harvest (e.g. tonging, dredging, hand-harvesting) is a destructive practice that reduces the height and structural complexity of subtidal oyster reefs (Lenihan \& Peterson 1998, 2004). In North Inlet, recreational oyster harvest has similar impacts on intertidal reefs where oyster removal and concomitant trampling reduces the height of the surficial shell layer (B. J. Toscano unpubl. data), defined as the extension of live and dead oyster shells above the sediment. Structurally complex reefs provide refuge for $P$. herbstii, and crab density is positively correlated with the volume of oyster clusters (Meyer 1994). Because larger crabs require more refuge space than smaller ones (Meyer 1994), reductions in the height of the surficial shell layer that occur with oyster harvesting could skew crab size structure towards a preponderance of smaller individuals. This reduction in crab body size and the more general loss of size diversity could have important cascading effects on the oyster reef food web.

Here, we tested how altered body size diversity in Panopeus herbstii influences their top-down effects on bivalves. To accomplish this we manipulated the 
number of size classes in $P$. herbstii, treating size classes as units of biodiversity, and measured aggregate and prey-specific consumption of the bivalve community in reefs. We also examined the relationship between the height of the surficial shell layer and $P$. herbstii body size in the field to determine the potential effects of oyster harvest on crab size structure in intertidal reefs.

\section{MATERIALS AND METHODS}

\section{Study site}

We conducted the experiment and sampled crabs in tidal creeks within North Inlet estuary $\left(33^{\circ} 20^{\prime} \mathrm{N}\right.$, $79^{\circ} 10^{\prime} \mathrm{W}$ ) in Georgetown, South Carolina, USA. North Inlet is an ocean-dominated estuary characterized by high average salinity (34 ppt) and a diurnal tidal cycle (mean tidal height of $1.5 \mathrm{~m}$ above mean lower low water) (Dame et al. 1986). The experiment was run from July through August 2010 and field sampling was conducted during August of 2010 and July of 2011.

\section{Field experiment}

In order to test the role of intraspecific body size diversity in mediating the predatory impacts of Panopeus herbstii, we manipulated body size diversity, or the number of size classes present in a population. We manipulated size diversity over 3 levels (1, 2 and 3 size classes present) while maintaining a constant total energy demand (Chalcraft \& Resetarits 2004) in a substitutive experimental design (Table 1). This design allows separation of the effects of population size distribution on consumption rates, without confounding associated allometric changes in metabolic rate that would arise if densities were held constant across size classes. This application of the substitutive design is analogous to that in species richness studies that alter the number of species while maintaining a constant overall density of individuals (e.g. Griffin et al. 2008, Toscano et al. 2010).

We determined densities of each size class that are equivalent in total energy demand using a power-law metabolic rate model where the total energy de- mand of a population $(T)$ of mean body size $(W)$ is a function of the metabolic rate $(I)$ of individuals times the number of individuals $(N)$ (Brown et al. 2004, Chalcraft \& Resetarits 2004):

$$
T_{W}=I \times N
$$

Metabolic rate $(I)$ scales as a power-law function of body size with a scaling exponent of roughly 0.75 (Leffler 1973, Brown et al. 2004). Thus, populations $i$ and $j$ of densities $N$ and mean body sizes $W$ have an equivalent total energy demand when the following equality is satisfied (Chalcraft \& Resetarits 2004):

$$
\frac{\ln \left(\frac{N_{i}}{N_{j}}\right)}{\ln \left(\frac{W_{i}}{W_{j}}\right)}=-0.75
$$

This energetic equivalence rule predicts that populations of equivalent total energy demand will have similar impacts on ecological processes related to metabolic rate (e.g. ingestion), without taking into account the roles of density-dependence or size specific foraging abilities (Chalcraft \& Resetarits 2004).

Specifically, this model yielded the prediction that 8 small crabs (19 to $23 \mathrm{~mm}$ carapace width [CW]), 4 medium crabs (29 to $33 \mathrm{~mm} \mathrm{CW}$ ) and 2 large crabs (38 to $42 \mathrm{~mm} \mathrm{CW}$ ) are approximately equivalent in total energy demand, and so these densities were used in assembling the various treatments (Table 1). This inverse relationship between density and body size as well as the overall crab biomass used in this experiment is similar to patterns in natural populations of Panopeus herbstii from North Inlet (Dame \& Vernberg 1982, McDonald 1982). Here, crabs exhibit

Table 1. Panopeus herbstii. Treatments in a substitutive experimental design used to examine the effects of body size diversity and size composition of xanthid crab populations held in wire cages on bivalve prey consumption. Each treatment was replicated 5 times in a randomized complete block design. Total energy demand $(T)$ units refer to densities of crabs from each size class that are approximately equivalent in total energy demand. Crab size classes (carapace width, CW): small $=19$ to

\begin{tabular}{|c|c|c|c|c|c|}
\hline \multirow{2}{*}{$\begin{array}{l}\text { Treatment } \\
\text { code }\end{array}$} & \multicolumn{3}{|c|}{ —Number of crabs per cage- } & \multirow{2}{*}{ 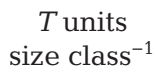 } & \multirow{2}{*}{$\begin{array}{c}\text { Size } \\
\text { diversity }\end{array}$} \\
\hline & Small & Medium & Large & & \\
\hline A & 24 & 0 & 0 & 3 & 1 \\
\hline B & 0 & 12 & 0 & 3 & 1 \\
\hline $\mathrm{C}$ & 0 & 0 & 6 & 3 & 1 \\
\hline $\mathrm{D}$ & 12 & 6 & 0 & 1.5 & 2 \\
\hline E & 12 & 0 & 3 & 1.5 & 2 \\
\hline F & 0 & 6 & 3 & 1.5 & 2 \\
\hline G & 8 & 4 & 2 & 1 & 3 \\
\hline $\mathrm{H}$ (control) & 0 & 0 & 0 & 0 & 0 \\
\hline
\end{tabular}
$23 \mathrm{~mm}$; medium $=29$ to $33 \mathrm{~mm}$; large 38 to $42 \mathrm{~mm}$ 


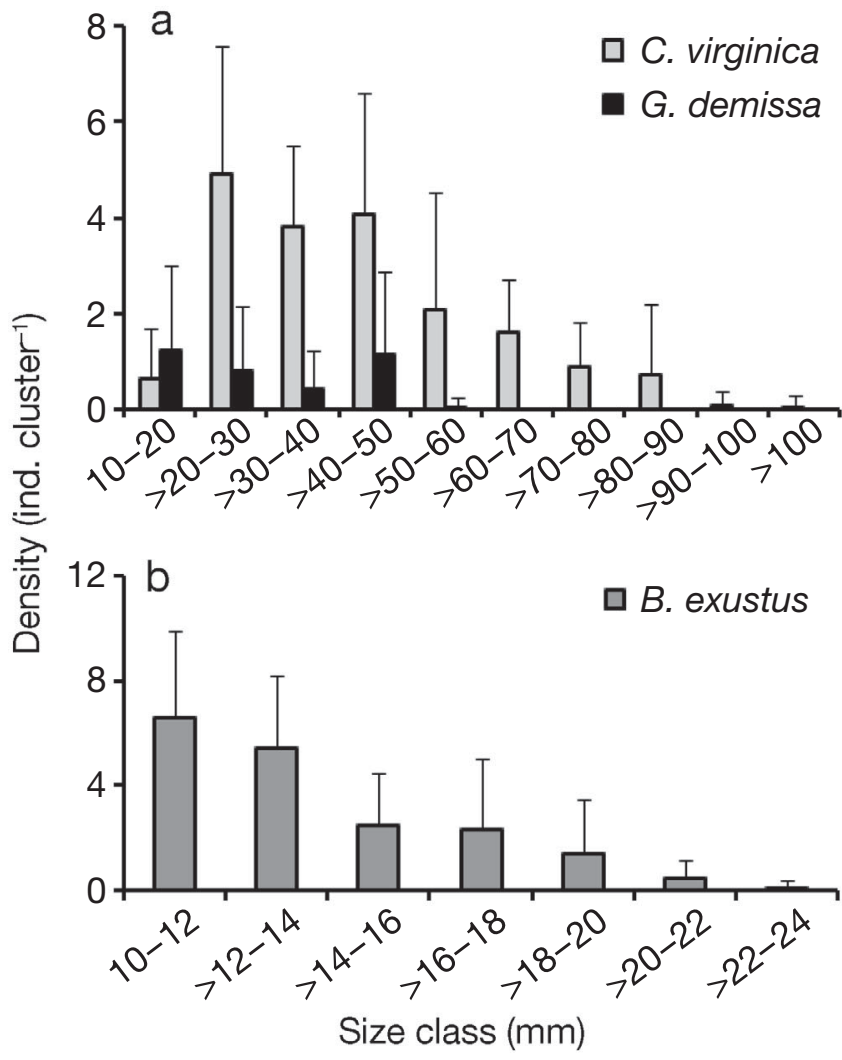

Fig. 1. Size frequency distributions of bivalves in intertidal oyster reefs in North Inlet, South Carolina. (a) Size frequency distributions of oysters Crassostrea virginica and the mussel Geukensia demissa. Only oysters on the exterior of the cluster, and thus vulnerable to predation on the time scale of our experiment, were enumerated. (b) Size frequency distribution of the mussel Brachidontes exustus. Densities for oyster clusters are mean $+1 \mathrm{SD}, N=13$. Clusters were randomly selected from reefs adjacent to the study site. Clusters varied in volume, and so densities here were scaled to the cluster volume $\left(5760 \mathrm{~cm}^{3}\right)$ used in field cages. Each cage received 2 clusters of this volume (see 'Materials and methods' for explanation of field experiment) fairly distinct size classes due to pulsed recruitment during late spring and summer (Dame \& Vernberg 1982, McDonald 1982). The experiment was conducted in a randomized complete block (temporal) design with a total of 5 blocks $(\mathrm{n}=5$ replicates per treatment).

We conducted the experiment within completely enclosed wire cages $(0.6[\mathrm{~L}] \times 0.5[\mathrm{~W}] \times 0.3[\mathrm{H}] \mathrm{m})$ lined with $0.25 \mathrm{~cm}$ polyethylene plastic sheet netting to prevent predator emigration or immigration. Each cage received 2 artificial oyster reefs $(0.3[\mathrm{~L}] \times 0.16$ $[\mathrm{W}] \times 0.12[\mathrm{H}] \mathrm{m})$ to recreate the intertidal oyster reefs inhabited by the study species. We used artificial reefs to precisely control the amount and type of prey in cages, as well as to standardize the complexity of the habitat because reef complexity is an important determinant of Panopeus herbstii bivalve consumption rates (Grabowski 2004, Grabowski \& Powers 2004). We created these reefs using oyster shells that had been dried and cleaned to remove epifauna. Holes were drilled in shell and shell clusters were assembled to mimic natural reef formations using plastic zip-ties. We then mounted the clusters on a fiberglass base and standardized by size as well as volume (measured through water displacement) to create a standardized reef matrix on which bivalve prey could be attached.

Two size classes of Brachidontes exustus and Crassostrea virginica, and a single size class of Geukensia demissa were offered to crabs in cages within the range of natural field densities (Fig. 1, Table 2). These 3 species are the most common constituents of the bivalve community in North Inlet's reefs (Dame 1979), and are all commonly found in the stomach contents of Panopeus herbstii from the field site (B. D. Griffen unpubl. data). Bivalve prey were

Table 2. Bivalve prey community used in all treatments. Numbers of prey were split evenly between 2 artificial reefs placed in each cage. Sub-samples of prey used in the experiment were randomly taken to estimate mean wet weight for each prey type. See 'Materials and methods' for procedure used to estimate dry tissue weight for each prey type

\begin{tabular}{|c|c|c|c|c|c|c|}
\hline \multirow{2}{*}{$\begin{array}{l}\text { Prey species } \\
\text { Size class }\end{array}$} & \multirow{2}{*}{$\begin{array}{c}\text { No. of } \\
\text { prey cage }{ }^{-1}\end{array}$} & \multicolumn{2}{|c|}{$\longrightarrow$ Prey size class -} & \multirow{2}{*}{$\begin{array}{c}N \\
\text { (sub-sample) }\end{array}$} & \multirow{2}{*}{$\begin{array}{c}\text { Tissue WW } \\
(\text { mean } \pm \text { SE) }(g)\end{array}$} & \multirow{2}{*}{$\begin{array}{l}\text { Tissue DW } \\
(\mathrm{g})\end{array}$} \\
\hline & & Length (mm) & WW (g) & & & \\
\hline \multicolumn{7}{|l|}{ Brachidontes exustus } \\
\hline Small & 20 & $15-18$ & $0.5-0.9$ & 201 & $0.68 \pm 0.009$ & 0.027 \\
\hline Large & 10 & $19-24$ & $1.0-2.0$ & 154 & $1.39 \pm 0.033$ & 0.055 \\
\hline \multicolumn{7}{|l|}{ Crassostrea virginica } \\
\hline Small & 12 & $35-44$ & $4.0-7.0$ & 183 & $5.73 \pm 0.075$ & 0.077 \\
\hline Large & 6 & $53-58$ & $11.0-14.0$ & 168 & $12.34 \pm 0.078$ & 0.159 \\
\hline Geukensia demissa & 4 & $34-44$ & $3.0-6.0$ & 74 & $4.31 \pm 0.106$ & 0.131 \\
\hline
\end{tabular}


attached to the artificial oyster reefs in the lab prior to trials. Oysters were glued (Gorilla Super Glue) to artificial reefs while mussels attached naturally through byssal thread formation. After attachment, artificial reefs with prey were placed in flow-through seawater tanks and individual bivalves were observed for normal filtering behavior over $24 \mathrm{~h}$. Predators and prey were collected from reefs adjacent to the study site and used only once in the experiment. Crabs were starved for $2 \mathrm{~d}$ prior to trials to standardize hunger levels.

Cages were deployed over a homogenous substrate of mud and sand adjacent to and the same tidal level as natural oyster reefs. First, sediment taken from the mud and sand flat adjacent to the experimental site was added to cages $(8 \mathrm{~cm})$. Artificial reefs with attached prey were then added. Next, 20 loose shells of similar dimensions, also dried and cleaned of epifauna, were scattered around the artificial reefs in each cage, again to recreate the complex, 3-dimensional habitat of natural oyster reefs. Finally, treatments were randomly assigned to cages and crabs were added. Trials lasted $48 \mathrm{~h}$ (4 tidal cycles) and cages were deployed and retrieved at low tide. At the conclusion of each trial, surviving prey were counted and mortality was determined as the loss of prey between the start and end of trials.

Prey biomass consumption (prey tissue dry weight consumed, g $48 \mathrm{~h}^{-1}$ ) was used as the response variable in all statistical analyses. Dry weight (DW) was determined as follows. First, sub-samples of prey used in the experiment were randomly taken to estimate the mean wet weight (WW) of each prey type (Table 2). Then, for a range of sizes of each prey type, soft tissue was removed and dried in a drying oven at $60^{\circ} \mathrm{C}$ for $24 \mathrm{~h}$ to determine the relationship between tissue WW and tissue DW using linear least-squares regression (Brachidontes exustus: $R^{2}=0.84$, Crassostrea virginica: $R^{2}=0.69$, Geukensia demissa: $R^{2}=$ 0.85 ). To estimate prey-specific consumption, the number of individual prey of each type that were missing at the end of trials was multiplied by the mean tissue DW for individuals of that prey type (as estimated through linear regression) (Table 2). The mean tissue DW of each individual prey species consumed by crabs was summed to derive the total consumption by the crab population in each cage.

We used a 2-factor analysis of variance (ANOVA) with temporal block and treatment as factors to test for differences in total consumption among the different treatments (Treatments A to G, Table 1). We then used the following planned linear contrasts to test specific hypotheses regarding the effects of crab size diversity and size composition on total consumption. (1) We compared the mean of the 3 single-size-class treatments $(\mathrm{A}, \mathrm{B}, \mathrm{C})$ to the most diverse 3-size class treatment (G) to test for the effect of body size diversity on total consumption. (2) We compared treatments with large crabs $(C, E, F, G)$ to treatments without (A, B, D) to test for the importance of large crabs in determining total consumption.

For treatments with 2 size classes present (D to F), we compared actual total consumption to that predicted by a substitutive model (Griffen 2006):

$$
E=\left(C_{1} \times C_{2}\right)^{0.5}
$$

where $E$ is expected total prey consumption and $C_{1}$ and $C_{2}$ are total consumption by each size class separately. This substitutive model predicts total consumption assuming additive effects (Griffen 2006). Two-tailed paired $t$-tests were used to compare predicted and observed total consumption to determine whether predation by different size classes did in fact combine additively (Griffen 2006). Total consumption data for these analyses were not significantly different from a normal distribution (Shapiro-Wilk normality test, $W=0.965, \mathrm{p}=0.325)$ and variances were homogenous among groups (Bartlett's test, test statistic $=11.9719, \mathrm{df}=6, \mathrm{p}=0.063$ ).

We used permutational multivariate ANOVAs (PERMANOVA) to test for differences among treatments in their effects on the bivalve prey assemblage. The first PERMANOVA tested for differences in prey resource use between the 3 single-size-class treatments (A to C). The second PERMANOVA tested for differences in prey resource use between the multiple size class treatments (D to G). Similarity percentage (SIMPER) analysis was used to determine which bivalve prey types contributed most to dissimilarity between treatments. SIMPER was conducted using PAST (Hammer et al. 2001). All other statistical analyses were conducted using R (v.2.12.0) (R Development Core Team 2010).

\section{Crab sampling}

To examine the relationship between the height of the surficial shell layer and crab body size, we sampled mean shell layer height and mean crab body size in $0.25 \mathrm{~m}^{2}$ quadrats $(\mathrm{N}=29)$ from intertidal oyster reefs that receive mild harvest pressure (B. J. Toscano pers. obs.). Quadrats were taken from reefs bordering tidal creeks that were roughly equivalent in area $\left(50 \mathrm{~m}^{2}\right)$ and shape. Mean shell layer height was measured as the distance between the mud layer 
and tops of shells at the corner of each quadrat (4 measurements for each quadrat were averaged). Crabs from within the quadrat were removed and mean size was determined. Because crab recruitment occurs over the spring and summer months (Dame \& Vernberg 1982, McDonald 1982), densities of new recruits were likely higher than if crabs were sampled at other times of the year. Thus, we only sampled crabs over $15 \mathrm{~mm} \mathrm{CW}$ to reduce the influence of new recruits. Only plots with $100 \%$ oyster shell cover were sampled to avoid confounding the known effects of percent shell cover on Panopeus herbstii populations (Meyer 1994). Since both variables were sampled with error, model II regression (reduced major axis regression) was used to test for a significant relationship between reef height and crab body size.

\section{RESULTS}

\section{Field experiment}

Prey mortality in predator-free controls was low ( $<3 \%$ for all prey species combined), indicating that prey mortality in predator-present treatments was due to predation. Total prey consumption differed across treatments (ANOVA, $F_{6,24}=5.207, \mathrm{p}=0.001$, Fig. 2) and temporal blocks (ANOVA, $F_{4,24}=3.939$, $\mathrm{p}=0.013)$. Mean total prey consumption of the 3 single-size-class treatments (A to C) did not differ from that when 3 size classes were combined (G) (linear contrast, $F_{1,24}=0.391, \mathrm{p}=0.538$, Fig. 2), though treatments that included large crabs had greater total consumption than treatments without large crabs (linear contrast, $F_{1,24}=14.422, \mathrm{p}=0.0009$, Fig. 2).

Small and medium crab combinations (Treatment D) and small and large crab combinations (Treatment E) had greater total consumption than substitutive model predictions based on consumption by each size class alone (paired $t$-tests, $t_{4}=-3.083, \mathrm{p}=0.037$ and $t_{4}=-3.921, \mathrm{p}=0.017$, for Treatments $\mathrm{D}$ and $\mathrm{E}$ respectively, Fig. 2). Total consumption by medium and large crabs together (Treatment F) however, did not differ significantly from the model prediction (paired $t$-test, $t_{4}=-0.894, \mathrm{p}=0.422$, Fig. 2).

Prey-specific consumption of the bivalve assemblage was dependent on treatment in single-sizeclass treatments (PERMANOVA, $F_{2,12}=16.616, \mathrm{p}=$ 0.01, Fig. 3a). SIMPER analysis revealed that Geukensia demissa was the prey type that contributed most to dissimilarity between small and large crab treatments, as well as between medium and large crab treatments (Fig. 4). Small Crassostrea virginica contributed most to dissimilarity between small and medium crabs (Fig. 4). In general, small crabs restricted their diet to small and large Brachidontes exustus. Medium crabs also consumed both size classes of $B$. exustus, while adding $G$. demissa and small $C$. virginica to their diet. Large crabs had the broadest diet and consumed the bivalve prey types most evenly. Specifically, large crabs increased their consumption of $G$. demissa and small $C$. virginica, while further adding large $C$. virginica to their diet and reducing consumption of $B$. exustus (Fig. 3a).

Treatment had a marginal effect on prey-specific consumption of the bivalve community when multiple size classes of crab were present (perMANOVA, $F_{3,16}=2.232, \mathrm{p}=0.06$, Fig. 3b). Consumption of Brachidontes exustus remained fairly consistent across multiple size class treatments (Fig. 3b), while consumption of large Crassostrea virginica, a much larger prey item (Table 2, Fig. 1), occurred only in the presence of larger crabs (Fig. 3b).

\section{Crab sampling}

The average body size of Panopeus herbstii was positively related to the height of the surficial shell layer (model II regression, $\mathrm{p}<0.0001, R^{2}=0.479$, Fig. 5) within intertidal oyster reefs.

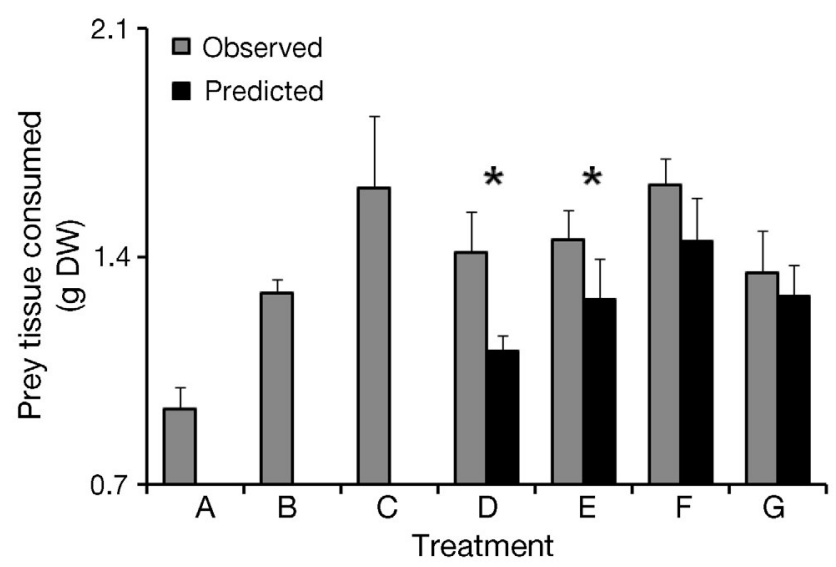

Fig. 2. Panopeus herbstii. Observed total prey consumption by crab populations in treatments (A to $G$ ) and substitutive model predictions for treatments with 2 crab size classes (D to F) and 3 size classes (G). See Table 1 for lettering and densities of different crab size classes within treatments. Values are total tissue dry weight (DW) consumed (means + SE; $g$ $48 \mathrm{~h}^{-1} ; \mathrm{n}=5$ replicates). Substitutive model predictions were calculated for each trial block separately using Eq. (3). ${ }^{*}$ Denotes significant difference between observed and predicted total consumption rate $(\alpha=0.05)$ 


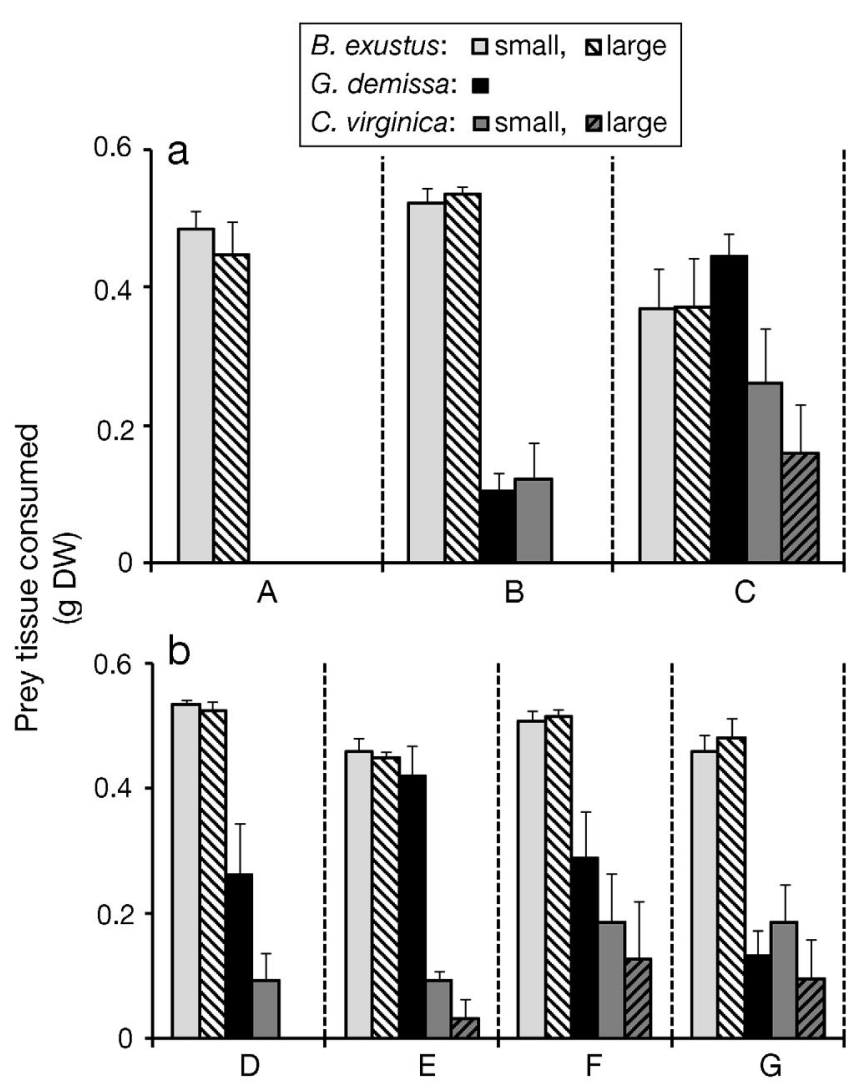

Fig. 3. Panopeus herbstii. Consumption of different bivalve prey types (Brachidontes exustus, Geukensia demissa, Crassostrea virginica). (a) Consumption in single-size-class treatments (A to C). (b) Consumption in 2 size class (D to F) and 3 size class (G) treatments. See Table 1 for lettering and densities of different crab size classes within treatments. Values are tissue dry weight (DW) consumed (means $+\mathrm{SE}$; g $48 \mathrm{~h}^{-1} ; \mathrm{n}=5$ replicates)

\section{DISCUSSION}

In the field experiment, crab body size diversity had no effect on total prey consumption when all 3 size classes were combined (Fig. 2). There was, however, some evidence of emergent, positive effects of size diversity in treatments with 2 size classes (Fig. 2). More important than diversity per se was the presence of large crabs. In treatments with large crabs present, total prey consumption was significantly greater than in treatments without large crabs (Fig. 2). In the field survey, we found a positive relationship between the height of the surficial shell layer and crab body size (Fig. 5). Because oyster harvest reduces the height of this shell layer, harvest can have substantial indirect effects on crab size structure. Specifically, oyster harvesting practices that reduce shell layer height and structural com-

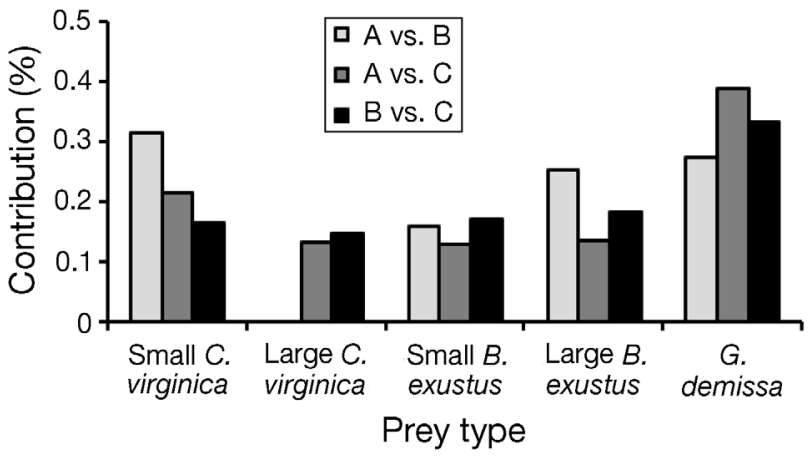

Fig. 4. Panopeus herbstii. Contribution of bivalve prey types (Crassostrea virginica, Geukensia demissa, Brachidontes exustus) to dissimilarity in xanthid crab diet between caged populations of small (A), medium (B) and large (C) crabs, as determined by SIMPER. See Table 2 for prey sizes and densities

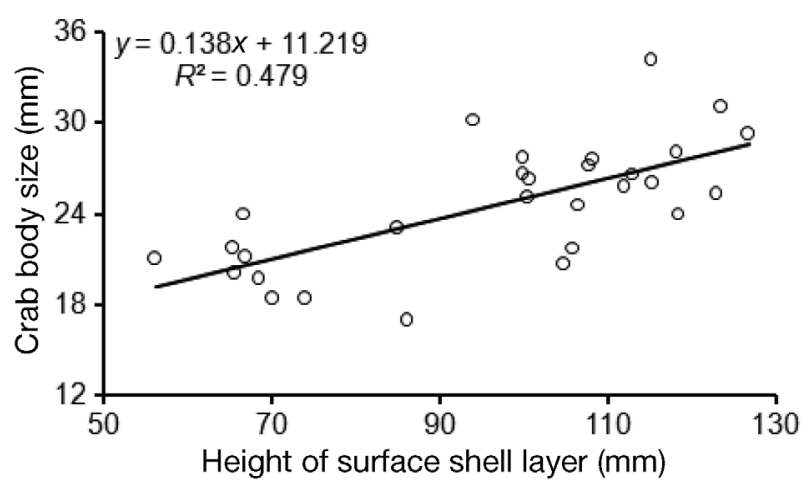

Fig. 5. Panopeus herbstii. Relationship between reef height and body size of xanthid crabs in intertidal oyster reefs in North Inlet, South Carolina. o: crab body size and reef height (means in $\mathrm{mm}$ ) sampled per $0.5 \mathrm{~m}^{2}$ quadrat $(N=29)$

plexity likely skew crab size structure towards a preponderance of small individuals, thereby reducing mean crab size in reefs. Due to the importance of large crabs in enhancing trophic transfer (Fig. 2), the loss of large crabs could substantially perturb the oyster reef food web.

Data on prey-specific consumption (Fig. 3) provides some insight into the mechanisms behind the total consumption results. The lack of a consistent effect of body size diversity was not surprising considering crab size classes did not discretely partition bivalve prey resources. Theoretical work predicts that increasing specialist consumer diversity should enhance aggregate resource use, while increasing generalist consumer diversity should have no effect (Ives et al. 2005). Empirical studies support this prediction, showing that partitioning among foragers can increase resource use efficiency (Finke \& Sny- 
der 2008, Griffin et al. 2008). Instead of partitioning among size classes, there was an increase in diet breadth with crab body size (i.e. nested diets, Fig. 3a). Smaller crabs were restricted in their resource use to the smallest prey types (small and large Brachidontes exustus: Fig. 3a) while larger crabs added larger prey to their diet while still consuming smaller prey, albeit at lower rates (Fig. 3a).

Positive effects of diversity were seen, however, in treatments with 2 size classes present. Both small and medium, as well as small and large crabs together consumed significantly more than the additive prediction (Fig. 2). In our substitutive experimental design, there is a reduction in size class density in the more diverse treatments (Table 1). This could have the effect of releasing crabs from intra-size class competition. This is congruent with the empirical findings that only size ranges that overlap in resource use exhibit density-dependence within species (Polis 1984) and that interference competition between crabs is strongest among similarly-sized conspecifics (Smallegange \& van der Meer 2007). This same mechanism has been observed in studies of predator richness, where multispecies predator assemblages have greater effects on ecological processes due to reduced intraspecific densities, and thus reduced resource overlap and interference (Griffin et al. 2008, Takizawa \& Snyder 2011). However, only with stomach contents analyses or additional treatments from an additive design (Griffen 2006, Byrnes \& Stachowicz 2009) can this hypothesis be assessed with the present system. It also is worth mentioning that while we limited the prey community to bivalves, a major food source for Panopeus herbstii, these crabs are omnivorous and will consume other food resources including other invertebrates, algae and detritus (authors' unpubl. data). Had these other food resources been incorporated into the study, partitioning between size classes may have been detected.

In treatments with large crabs, total prey consumption was enhanced relative to treatments without large crabs. This was due to the ability of large crabs to consume the larger bivalve prey types (Fig. 3a) that were not consumed by smaller crabs on the time scale of our experiment. These resource use differences among different sized crabs were likely driven by morphological constraints on foraging, and a trade-off in the foraging capabilities of small and large crabs (Seed \& Hughes 1997, Morton \& Harper 2008). The major claw of small crabs, the functional organ used to handle prey, is not large and robust enough to crush the large prey types outright, and so these prey gain a size refuge in treatments with small crabs on the time scale of our experiment (Fig. 3a). However, smaller crabs are more efficient than large crabs at consuming Brachidontes exustus in this study (Fig. 3a). This is supported by functional response data in which small crabs consume more small $B$. exustus at low prey densities (authors' unpubl. data). Thus, under predation by large crabs, smaller prey may gain a partial refuge from predation.

While our experiment revealed these short-term changes in predation with crab size structure, size structure could also affect bivalve population dynamics, the long-term stability of the reef community, and the recovery of the community from disturbance. While our data suggests that the loss of large crabs may free larger oysters from predation, higher consumption rates on small, or newly settled bivalves (e.g. oyster spat) by small crabs could impede the recovery of reefs from perturbation. Thus the loss of large crabs (and predominance of smaller crabs) could affect the recruitment and assembly of the bivalve community. These long-term consequences of changes in predator size structure are unknown, but likely important for the management of imperiled reef systems worldwide.

Ontogenetic diet expansion, as detected in the present study, is common in consumers (Polis 1984, Werner \& Gilliam 1984, Woodward \& Hildrew 2002, Woodward et al. 2005, Arim et al. 2010) and particularly those that are limited by the size of their feeding apparatus (e.g. mouth gape size in fish and amphibians, claw size in crabs). In such consumers, large individuals are functionally unique as they can consume prey that smaller individuals cannot. In these cases, the loss of size structure, and particularly the loss of large individuals, can have important implications for lower trophic levels; without large predator individuals, large prey items will be freed from top-down control. This is an important applied issue because human harvesting practices often remove the largest individuals in a population, skewing population size structure towards smaller individuals and reducing intraspecific body size diversity. Thus understanding how intraspecific size diversity in predator populations mediates their community impacts is critical to ecosystem-based management practices, which in part focus on the community-wide effects of harvesting a species.

Reduced top-down control resulting from the harvesting of large individuals was recently observed by Shackell et al. (2010) who reported that exponential increases in prey abundance over $38 \mathrm{yr}$ in a northwest Atlantic fishery are related to declines in the 
average body size of exploited fish predator species. Total predator biomass remained constant over this time period, but the body mass of predators declined by $60 \%$ due to the preferential exploitation of large individuals. This loss of large individuals initiated a trophic cascade in which prey were freed from topdown control, in turn reducing zooplankton and increasing phytoplankton abundances. Our study provides a mechanistic basis that elucidates how such a broad-scale effect can transpire with the loss of large size classes from predator populations.

In sum, previous studies document the importance of predator species richness (Bruno \& Cardinale 2008), yet aspects of intraspecific predator diversity remain to be fully incorporated into the larger framework of predator biodiversity. Our study has addressed one component of intraspecific phenotypic diversity, though other components of intraspecific diversity are likely also important in driving ecological or even ecosystem level processes (e.g. individual specialization, resource use differences due to polymorphism; Bolnick et al. 2003). As with size diversity, these additional forms of diversity are being altered by humans. For example, exploitation often targets certain animal personality types where the boldest individuals more frequently approach and are caught in traps (Biro \& Post 2008). This removal of particularly bold individuals can alter the intraspecific behavioral diversity of a population (Biro \& Post 2008). With continued alterations to all organizational levels of biodiversity, the challenge is to move beyond species richness manipulations alone to gain a more holistic understanding of the functional importance of biodiversity.

Acknowledgements. Funding was provided by the SlocumLunz Foundation, the University of South Carolina, the International Women's Fishing Association and the South Carolina Wildlife Federation. Thanks to D. R. Chalcraft for advice on experimental design and B. Newsom for laboratory assistance. This manuscript was greatly improved by comments from anonymous reviewers.

\section{LITERATURE CITED}

Arim M, Abades SR, Laufer G, Loureiro M, Marquet PA (2010) Food web structure and body size: trophic position and resource acquisition. Oikos 119:147-153

Biro PA, Post JR (2008) Rapid depletion of genotypes with fast growth and bold personality traits from harvested fish populations. Proc Natl Acad Sci USA 105:2919-2922

Bisker R, Castagna M (1987) Predation on single spat oysters Crassostrea virginica (Gmelin) by blue crabs Callinectes sapidus Rathbun and mud crabs Panopeus herbstii Milne-Edwards. J Shellfish Res 6:37-40

Bolnick DI, Svanback R, Fordyce JA, Yang LH, Davis JM,
Hulsey CD, Forister ML (2003) The ecology of individuals: incidence and implications of individual specialization. Am Nat 161:1-28

Bolnick DI, Amarasekare P, Araujo MS, Burger R and others (2011) Why intraspecific trait variation matters in community ecology. Trends Ecol Evol 26:183-192

> Brose U (2010) Body-mass constraints on foraging behaviour determine population and food-web dynamics. Funct Ecol 24:28-34

> Brown JH, Gillooly JF, Allen AP, Savage VM, West GB (2004) Toward a metabolic theory of ecology. Ecology 85: 1771-1789

> Bruno JF, Cardinale BJ (2008) Cascading effects of predator richness. Front Ecol Environ 6:539-546

> Byrnes JE, Stachowicz JJ (2009) The consequences of consumer diversity loss: different answers from different experimental designs. Ecology 90:2879-2888

Chalcraft DR, Resetarits WJ (2004) Metabolic rate models and the substitutability of predator populations. J Anim Ecol 73:323-332

Dame RF (1979) The abundance, diversity and biomass of macrobenthos on North Inlet, South Carolina, intertidal oyster reefs. Proc Natl Shellfish Assoc 69:6-10

Dame RF, Libes S (1993) Oyster reefs and nutrient retention in tidal creeks. J Exp Mar Biol Ecol 171:251-258

Dame RF, Patten BC (1981) Analysis of energy flows in an intertidal oyster reef. Mar Ecol Prog Ser 5:115-124

> Dame RF, Vernberg FJ (1982) Energetics of a population of the mud crab Panopeus herbstii (Milne Edwards) in the North Inlet estuary, South Carolina. J Exp Mar Biol Ecol 63:183-193

> Dame R, Chrzanowski T, Bildstein K, Kjerfve B and others (1986) The outwelling hypothesis and North Inlet, South Carolina. Mar Ecol Prog Ser 33:217-229

Elton CS (1927) Animal ecology. Sedgewick and Jackson, London

Finke DL, Snyder WE (2008) Niche partitioning increases resource exploitation by diverse communities. Science 321:1488-1490

> Finke DL, Snyder WE (2010) Conserving the benefits of predator biodiversity. Biol Conserv 143:2260-2269

> Fisher JAD, Frank KT, Leggett WC (2010) Breaking Bergmann's rule: truncation of Northwest Atlantic marine fish body sizes. Ecology 91:2499-2505

> Grabowski JH (2004) Habitat complexity disrupts predatorprey interactions but not the trophic cascade on oyster reefs. Ecology 85:995-1004

> Grabowski JH, Powers SP (2004) Habitat complexity mitigates trophic transfer on oyster reefs. Mar Ecol Prog Ser 277:291-295

> Griffen BD (2006) Detecting emergent effects of multiple predator species. Oecologia 148:702-709

> Griffin JN, De la Haye KL, Hawkins SJ, Thompson RC, Jenkins SR (2008) Predator diversity and ecosystem functioning: density modifies the effect of resource partitioning. Ecology 89:298-305

Hammer Ø, Harper DAT, Ryan PD (2001) PAST: paleontological statistics software package for education and data analysis. Palaeo Elec 4:1-9

Hardy AC (1924) The herring in relation to its animate environment. Part 1. The food and feeding habits of the herring with special reference to the coast of England. Fishery Investig Ser 2 7:1-53

Hillebrand H, Matthiessen B (2009) Biodiversity in a complex world: consolidation and progress in functional 
biodiversity research. Ecol Lett 12:1405-1419

Ives AR, Cardinale BJ, Snyder WE (2005) A synthesis of subdisciplines: predator-prey interactions, and biodiversity and ecosystem functioning. Ecol Lett 8:102-116

Kneib RT, Stiven AE (1982) Benthic invertebrate responses to size and density manipulations of the common mummichog, Fundulus heteroclitus, in an intertidal salt marsh. Ecology 63:1518-1532

Law R (2000) Fishing, selection, and phenotypic evolution. ICES J Mar Sci 57:659-668

Leffler CW (1973) Metabolic rate in relation to body size and environmental oxygen concentration in two species of xanthid crabs. Comp Biochem Physiol A 44:1047-1052

Lenihan HS, Peterson CH (1998) How habitat degradation through fishery disturbance enhances impacts of hypoxia on oyster reefs. Ecol Appl 8:128-140

Lenihan HS, Peterson CH (2004) Conserving oyster reef habitat by switching from dredging and tonging to diverharvesting. Fish Bull 102:298-305

McDermott J (1960) The predation of oysters and barnacles by crabs of the family Xanthidae. Proc Pennsylvania Acad Sci 34:199-211

McDonald J (1982) Divergent life history patterns in the cooccurring intertidal crabs Panopeus herbstii and Eurypanopeus depressus (Crustacea: Brachyura: Xanthidae). Mar Ecol Prog Ser 8:173-180

> Meyer DL (1994) Habitat partitioning between the xanthid crabs Panopeus herbstii and Eurypanopeus depressus on intertidal oyster reefs (Crassostrea virginica) in southeastern North Carolina. Estuaries 17:674-679

Milke LM, Kennedy VS (2001) Mud crabs (Xanthidae) in Chesapeake Bay: claw characteristics and predation on epifaunal bivalves. Invertebr Biol 120:67-77

Mittelbach GG (1981) Foraging efficiency and body size: a study of optimal diet and habitat use by bluegills. Ecology 62:1370-1386

Morton B, Harper EM (2008) Predation upon Mytilus galloprovincialis (Mollusca: Bivalvia: Mytilidae) by juvenile Carcinus maenas (Crustacea: Decapoda) using mandibular chipping. J Mar Biol Assoc UK 88:563-568

Okuyama T (2008) Individual behavioral variation in predator-prey models. Ecol Res 23:665-671

$>$ Polis GA (1984) Age structure component of niche width and intraspecific resource partitioning: can age groups function as ecological species? Am Nat 123:541-564

R Development Core Team (2010) R: a language and environment for statistical computing. R Foundation for Statistical Computing, Vienna, www.r-project.org

Reiss J, Bridle JR, Montoya JM, Woodward G (2009) Emerging horizons in biodiversity and ecosystem functioning research. Trends Ecol Evol 24:505-514

Editorial responsibility: Richard Osman,

Edgewater, Maryland, USA
Rudolf VHW (2007) Consequences of stage-structured predators: cannibalism, behavioral effects, and trophic cascades. Ecology 88:2991-3003

> Rudolf VHW, Lafferty KD (2011) Stage structure alters how complexity affects stability of ecological networks. Ecol Lett 14:75-79

Schmitz OJ (2007) Predator diversity and trophic interactions. Ecology 88:2415-2426

Schmitz OJ (2009) Effects of predator functional diversity on grassland ecosystem function. Ecology 90:2339-2345

Seed R (1980) Predator-prey relationships between the mud crab Panopeus herbstii, the blue crab, Callinectes sapidus and the Atlantic ribbed mussel Geukensia (= Modiolus) demissa. Estuar Coast Mar Sci 11:445-458

Seed R, Hughes RN (1997) Chelal characteristics and foraging behaviour of the blue crab Callinectes sapidus Rathbun. Estuar Coast Shelf Sci 44:221-229

> Shackell NL, Frank KT, Fisher JAD, Petrie B, Leggett WC (2010) Decline in top predator body size and changing climate alter trophic structure in an oceanic ecosystem. Proc Biol Sci 277:1353-1360

> Smallegange IM, van der Meer J (2007) Interference from a game theoretical perspective: shore crabs suffer most from equal competitors. Behav Ecol 18:215-221

Stoner AW, Livingston RJ (1984) Ontogenetic patterns in diet and feeding morphology in sympatric Sparid fishes from seagrass meadows. Copeia 174-187

Takizawa T, Snyder WE (2011) Predator biodiversity increases the survivorship of juvenile predators. Oecologia 166:723-730

Toscano BJ, Fodrie FJ, Madsen SL, Powers SP (2010) Multiple prey effects: agonistic behaviors between prey species enhances consumption by their shared predator. J Exp Mar Biol Ecol 385:59-65

> Werner EE (1992) Individual behavior and higher-order species interactions. Am Nat 140:S5-S32

Werner EE, Gilliam JF (1984) The ontogenetic niche and species interactions in size-structured populations. Annu Rev Ecol Syst 15:393-425

- Whetstone JM, Eversole AG (1981) Effects of size and temperature on mud crab, Panopeus herbstii, predation on hard clams, Mecenaria mercenaria. Estuaries 4:153-156

Williams AB (1984) Shrimps, lobsters, and crabs of the Atlantic coast of the Eastern United States, Maine to Florida. Smithsonian Institution Press, Washington, DC

Woodward G, Hildrew AG (2002) Body-size determinants of niche overlap and intraguild predation within a complex food web. J Anim Ecol 71:1063-1074

Woodward G, Ebenman B, Emmerson M, Montoya JM, Olesen JM, Valido A, Warren PH (2005) Body size in ecological networks. Trends Ecol Evol 20:402-409

Submitted: July 26, 2011; Accepted: October 21, 2011

Proofs received from author(s): January 4, 2012 